\title{
Main publications by Xiaoye Wang
}

\section{AUTHORED BOOKS}

1. Monopolies and Competition in the Chinese Economy - A Comparative Analysis of U.S. and German Merger Control, J.C.B. Mohr (Germany) 1993

2. Anti-Monopoly Issues in Mergers and Acquisitions, Law Press China (法律出版社) 1996

3. Competition Law Research, China Legal Publishing House (中国法制出版社) 1999

4. EU Competition Law, China Legal Publishing House (中国法制出版社) 2001

5. Competition Law, Social Sciences Academic Press (China) (社会科学文献出版社) 2007

6. Wang Xiaoye on the Antitrust Law, Social Sciences Academic Press (China) (社会科学文献出版社) 2010

7. Anti-Monopoly Law, Law Press China (法律出版社) 2011

8. The Evolution of China's Anti-Monopoly Law, Edward Elgar 2014

\section{EDITED BOOKS}

1. Anti-Monopoly Law and the Market Economy, Law Press China (法律出版社) 1998

2. Competition Law and Economic Development, Social Sciences Academic Press (China) (社会科学文献出版社) 2003

3. New Developments in Competition Law Under Economic Globalisation, Social Sciences Academic Press (China) (社会科学文献出版社) 2005

4. Economic Law, Social Sciences Academic Press (China) (社会科学文献出版社) 2005, 2010 (2nd edn)

5. Economic Law, China Social Sciences Press (中国社会科学出版社) 2010

6. Hotspot Issues in Anti-Monopoly Legislation, Social Sciences Academic Press (China) (社会科学文献出版社) 2007

7. A Detailed Explanation of the Anti-Monopoly Law of the People's Republic of China, Intellectual Property Publishing House (知识产权出版社) 2008 
8. New Developments in Economic Law, China Social Sciences Press (中国社会科学出版社) 2008

9. Major Issues in the Implementation of Anti-Monopoly Law, Social Sciences Academic Press (China) (社会科学文献出版社) 2010

10. Capacity Building in Competition Law Enforcement, Social Sciences Academic Press (China) (社会科学文献出版社) 2012

11. Market Definition in the Antitrust Law, Social Sciences Academic Press (China) (社会科学文献出版社) 2014

\section{CO-AUTHORED BOOK}

1. Co-authored with Jessica Su, Competition Law in China, Kluwer Law International (the Netherlands) (2011)

\section{CHINESE-LANGUAGE PAPERS ${ }^{1}$}

1. On the Theoretical Bases of the Foreign Law Applicable to the ForeignRelated Civil Cases, CASS Journal of Law (法学研究) 1984, Issue No. 2

2. Issues on the Applicable Law in Foreign Direct Investment Contracts, Journal of Graduate School of Chinese Academy of Social Sciences (中国社会科学院研究生院学报) 1985, Issue No. 1

3. Issues on Applicable Law in International Technology Transfer Contracts, Law Quarterly (法学季刊) 1985, Issue No. 2

4. On the Basic Principles of Applicable Law in Foreign-Related Economic Contracts, CASS Journal of Law (法学研究) 1985, Issue No. 5

5. The Current Situation and Developments in Private International Law in the Federal Republic of Germany, Law Study and Research (法律学习与研究) 1998 Issue No. 1

6. Merger Control in the Federal Republic of Germany, CASS Journal of Law (法学研究) 1990, Issue No. 3

7. Merger Control in the United States and its New Developments, China Legal Science (中国法学) 1990, Issue No. 5

8. EC Anti-Dumping Law and China's Foreign Trade, CASS Journal of Law (法学研究) 1993, Issue No. 1

9. EC Competition Law and its New Developments, Translation and Review of Foreign Laws (外国法译评) 1993, Issue No. 3

1 To date, I have published about 200 Chinese-language articles. The following is a list of selected articles. 
10. The Current Situation and Prospects of International Harmonisation of Anti-Monopoly Law, Translation and Review of Foreign Laws (外国法译评) 1995, Issue No. 1

11. Monopoly is the Enemy of Fair Competition, People's Daily (人民日报) 17 February 1995

12. Anti-Monopoly Law and International Trade, International Trade Journal (国际贸易问题) 1995, Issue No. 8

13. The Regulation of Cartels in German Competition Law, Jurists' Review (法学家) 1995, Issue No. 4

14. Anti-Monopoly Law in a Socialist Market Economy, Social Sciences in China (中国社会科学) 1996, Issue No. 1

15. The Framework of China's Anti-Monopoly Law, CASS Journal of Law (法学研究) 1996, Issue No. 4

16. The Regulation of the Market Behaviour of Public Enterprises Requires Anti-Monopoly Law, CASS Journal of Law (法学研究) 1997, Issue No. 5

17. Reform of the Social Security System in Europe, China Social Insurance (中国社会保险) 1997, Issue No. 7

18. EU Anti-Dumping Law and China's Exports to the European Union, International Trade Journal (国际贸易问题) 1998, Issue Nos. 1 and 2

19. The Legal Regulation of Administrative Restrictions on Competition, CASS Journal of Law (法学研究) 1998, Issue No. 3

20. Effective Competition - Chinese Competition Policy and the Model AntiMonopoly Law, Jurists' Review (法学家) 1998, Issue No. 2

21. EU Merger Control Regulation and its New Developments, in Economic Law Research (经济法研究) 2000, Vol. 1, Yang Zixuan (ed.), Peking University Press (北京大学出版社)

22. State-Owned Enterprises in EC Competition Law, Translation and Review of Foreign Laws (外国法译评) 1999, Issue No. 3

23. Disputes on the Extraterritorial Application of Anti-Monopoly Law From Merger Control Perspective, Intertrade (国际贸易) 1999, Issue No. 2

24. Anti-Monopoly Law and Industry Price Self-Discipline, Intertrade (国际贸易) 1999, Issue No. 5

25. On Anti-Monopoly Legislation in the Telecommunications Industry, Intertrade (国际贸易) 1999, Issue No. 8

26. Legal Thinking on Dumping Behaviour, Intertrade (国际贸易) 1999, Issue No. 11

27. The Challenge of Mega Cross Border Mergers to Anti-Monopoly Law, CASS Journal of Law (法学研究) 1999, Issue No. 5

28. EU Anti-Dumping Law and its Effect on China, Law Review (法学评论) 1999, Issue No. 3 
29. Hazards of Administrative Restrictions on Competition, Inside Information on Economic Reform (改革内参) 1999, Issue No. 19

30. State Aid in EU Competition Law, Intertrade (国际贸易) 2000, Issue No. 3

31. The Sixth Revision to Germany's Act Against Restraints on Competition, German Studies (德国研究) 2000, Issue No. 1

32. Abuse of Dominant Position in EC Competition Law, Intertrade (国际贸易) 2000, Issue No. 5

33. Why the US Department of Justice is Suing Microsoft, Intertrade (国际贸易) 2000, Issue No. 4

34. Chinese Economic Law Must Change Upon WTO Accession, International Trade News (国际经贸消息) 1 June 2000

35. The Antitrust Paradox - Why Did the US Government Clear the Merger Between America Online and Time Warner?, Intertrade (国际贸易) 2000, Issue No. 2

36. The AOL-Time Merger and the Breakup of Microsoft Are Not Paradoxes, Money China (财经界) 2000, Issue No. 3

37. On Agreements that Restrict Competition, Study on China Administration for Industry \& Commerce (中国工商管理研究) 2000, Issue No. 4

38. Speed Up the Legislation of Anti-Monopoly, China Industry and Commerce News (中国工商报) 13 June 2000

39. The Legislation of the Anti-Monopoly Law Should Not Be Delayed, Legal Daily (法制日报) 23 April 2000

40. EC Merger Control, Intertrade (国际贸易) 2000, Issue No. 10

41. Looking at China's Anti-Monopoly Legislation from the Microsoft Case, Chinese Lawyer (中国律师) 2000, Issue No. 9

42. Comments on the Objectives and Mission of EC Competition Law, Intertrade (国际贸易) 2001, Issue No. 9

43. EC Competition Policy and Industry Policy, Intertrade (国际贸易) 2001, Issue No. 10

44. Intellectual Property Rights in EC Competition Law, Global Law Review (环球法律评论) 2001, Issue No. 2

45. Penalty in EC Competition Law, Study on China Administration for Industry \& Commerce (中国工商管理研究) 2001, Issue No. 3

46. Anti-Monopoly Legislation Cannot Be Delayed Further, Legal Daily (法制日报) 6 March 2002

47. US Antitrust Law and its New Developments, Intertrade (国际贸易) 2002, Issue No. 3

48. Comments on the Extraterritorial Application of US Antitrust Law, Anhui University Law Review (安徽大学法学评论) 2002, Issue No. 2 
49. How Much Longer Do We Have to Wait for China's Anti-Monopoly Law?, Social Sciences Weekly (社会科学报) 8 August 2002

50. The Formulation of China's Anti-Monopoly Law, Law Science Magazine (法学杂志) 2002, Issue No. 5

51. On Anti-Monopoly Law, Ninth NPC Standing Committee Law Lectures, China Democracy and Legal System Publishing House (中国民主法制出版社) 2003

52. WTO Accession and the Formulation of China's Anti-Monopoly Law, CASS Journal of Law (法学研究) 2003, Issue No. 2

53. Anti-Monopoly Issues Related Intellectual Property Rights - From Perspective Cisco v Huawei Case, 21 Century Business Insights (21世纪经济导报) 18 March 2003

54. The Impact of Competition Policy on International Trade, Intertrade (国际贸易) 2003, Issue No. 6

55. Some Issues in China's Anti-Monopoly Legislation, Journal of Capital Normal University (Social Science Edition)（首都师范大学学报： 社会科学版) 2003, Issue No. 2

56. WTO Competition Policy and its Influence in China, Social Sciences in China (中国社会科学) 2005, Issue No. 5

57. International Cooperation in the Field of Competition Policy, Intertrade (国际贸易) 2003, Issue No. 7

58. Reflections on the Improvement of Chinese Competition Law and Competition Mechanism, Intertrade (国际贸易) 2003, Issue No. 10

59. Legal Issues Surrounding Comparative Advertising, Intertrade (国际贸易) 2003, Issue No. 11

60. Economic Analysis of Vertical Agreements that Restrict Competition, Cross-Strait Law Review (月旦民商法杂志) 2004, Issue No. 3

61. Prospects of China's Anti-Monopoly Legislation and its Review, China Mergers and Acquisitions Yearbook 2004, Posts \& Telecom Press (人民邮电出版社) 2004

62. Anti-Monopoly Regulation of the Abuse of Intellectual Property, Law Science (法学) 2004, Issue No. 3

63. Relevant Market in Anti-Monopoly Law, Intertrade (国际贸易) 2004, Issue No. 2

64. The Exhaustion Doctrine in Intellectual Property Rights and its New Developments, Intertrade (国际贸易) 2004, Issue No. 3

65. Legal Reflections on Dumping Behaviours, Price: Theory \& Practice (价格理论与实践) 2004, Issue No. 6

66. The Relationship Between Anti-Unfair Competition Law and Adjacent Laws, Intertrade (国际贸易) 2004, Issue No. 7 
67. Problems in China's Anti-Monopoly Legislation, Faren Magazine (法人) 2004, Issue No. 7

68. Per Se Illegal Cartels and Their Legal Consequences, Intertrade (国际贸易) 2004, Issue No. 8

69. Rule of Reason Cartels, Intertrade (国际贸易) 2004, Issue No. 9

70. Some Theoretical Issues in Competition Law, in Economic Law Forum, Vol. 2, Li Changqi (ed.), Qunzhong Publishing House (群众出版社) 2005

71. The Prospects of International Harmonisation of Anti-Monopoly Laws, in Economic Law Forum, Vol. 5, Xu Jie (ed.), Law Press China (法律出版社) 2004

72. Research on Prohibiting Abuse of Market Dominant Position, Financial and Economic Law Review (月旦财经法杂志) 2005, Issue No. 1

73. Regulation of Abuse of Dominance by Public Enterprises, Xinhua Wenzhai (新华文摘) 2005, Issue No. 9

74. Development of the Non-Public Economy to Eliminate Administrative Monopoly, China Reform (中国改革) 2005, Issue No. 6

75. Regulating the Competition Restricting Conduct of Multinational Companies, in New Developments in Competition Law Under Economic Globalisation, Wang Xiaoye (ed.), Social Sciences Academic Press (China) (社会科学文献出版社) 2005

76. Government Behaviour in Anti-Monopoly Law, in New Developments in Competition Law Under Economic Globalisation, Wang Xiaoye (ed.), Social Sciences Academic Press (China) (社会科学文献出版社) 2005

77. Free Competition and Fair Competition in Competition Law, Anhui University Law Review (安徽大学法律评论) 2005

78. Comments on China's Current Merger Control Rules, Intertrade (国际贸易) 2005, Issue No. 5

79. Market Access of the Non-Public Economy and Anti-Monopoly Law, Jurists' Review (法学家) 2005, Issue No. 3

80. How Can Merger Control Only Limit Foreign Investors? Social Sciences Weekly (社会科学报) 26 May 2005

81. Cartels in Anti-Monopoly Law, Cross-Strait Law Review (月旦民商法杂志) 2006, Issue No. 6

82. The Status of Competition Law in the Market Economy, Journal of Central South University for Social Science Edition (中南大学学报社会科学版) 2006, Issue No. 1

83. The Relationship Between Anti-Monopoly Enforcement Agencies and Industry Regulators, China Economic Times (中国经济时报) 14 August 2006

84. Problems of Multiple Anti-Monopoly Enforcement Agencies, China Development Observation (中国发展观察) 2006, Issue No. 9 
85. Draft Anti-Monopoly Law Still Needs to Cross Four Obstacles, Legal Daily (法制日报) 29 October 2006

86. The Role of Anti-Monopoly Law in Building a Harmonious Society, Study Times (学习时报) 20 November 2006

87. Legal Proposals for the Reform of Monopoly Industries, Study Times (学习时报) 29 January 2007

88. Some Issues Surrounding the Anti-Monopoly Enforcement Authority in China, Dongyue Tribune (东岳论丛) 2007, Issue No. 1

89. Some Topical Issues in China's Anti-Monopoly Legislation, China Law (中国法律) 2007, Issue No. 1

90. Some Problems in the Latest Draft of the Anti-Monopoly Law, Journal of Shanghai Jiaotong University for Philosophy and Social Sciences (上海交通大学学报哲学社会科学版) January 2007

91. Legal Issues Related to the Abuse of Intellectual Property Rights to Restrict Competition, Social Sciences in China (中国社会科学) 2007, Issue No. 4

92. Anti-Monopoly Law in the Compulsory Licensing of Intellectual Property, Modern Law Science (现代法学) 2007, Issue No. 5

93. Anti-Monopoly Law - A Milestone in Economic Reform, Legal Daily (法制日报) 2 September 2007

94. Paying Attention to the Serious Challenges that will Face the Initial Enforcement of Anti-Monopoly Law, Legal Daily (法制日报) 2 September 2007

95. Anti-Monopoly Law is a Basic Law to Regulate the Order of Market Competition, Chinese Cadres Tribune (中国党政干部论坛) 2007, Issue No. 9

96. Why Microsoft Lost the Case in the European Court of Justice, China Youth Daily (中国青年报) 14 October 2007

97. Anti-Monopoly Bottleneck, Caijing Annual Edition China 2008: Forecasts and Strategies (财经年刊2008：预测与战略) 2008

98. The 'Public Interest' Gridlock in Anti-Monopoly Law, Inside Information on Economic Reform (改革内参) 2008, Issue No. 1

99. The Legislative Purpose of China's Anti-Monopoly Law, Journal of East China University of Political Science and Law (华东政法大学学报) 2008, Issue No. 2

100. The Formulation and Implementation of China's Anti-Monopoly Law, Blue Book of Rule of Law No. 6 (中国法治发展报告蓝皮书 No.6) 2008

101. Comment on Concentrations of Undertakings Under the Anti-Monopoly Law of the People's Republic of China, Law Science Magazine (法学杂志) 2008, Issue No. 1 
102. Extraterritorial Application of China's Anti-Monopoly Law, Journal of Shanghai University of Finance and Economics (上海财经大学学报) 2008, Issue No. 1

103. 'Public Interest' in Anti-Monopoly Law, CASS Review (中国社会科学院院报) 12 June 2008

104. Comment on the Anti-Monopoly Law of the People's Republic of China, CASS Journal of Law (法学研究) 2008, Issue No. 4

105. My Anti-Monopoly Law Research Path, CASS Review (中国社会科学院院报) 2 September 2008

106. Compulsory Licensing of Intellectual Property Related Technical Standards, Contemporary Law Review (当代法学) 2008, Issue No. 5

107. China's Anti-Monopoly Enforcement Agencies should Refuse to Clear the BHP-Rio Tinto Merger, China Economic Times (中国经济时报) 5 November 2008

108. Anti-Monopoly Regulation of Exploitative Abuses, Price: Theory \& Practice (价格理论与实践) 2008, Issue No. 10

109. Anti-Monopoly Law is a Symbolic Law in a Socialist Market Economy, Chinese Academy of Social Sciences Report - Leaders Reference (中国社 会科学院要报一领导参阅) 2008, Issue No. 30

110. Anti-Monopoly Law is a Basic Law to Protect Order in Market Economies, Tenth NPC Standing Committee Law Lectures, China Democracy and Legal System Publishing House (中国民主法制出版社) 2008

111. Anti-Monopoly Law and Economic Reform in China, Oriental Law (东方 法学) 2009, Issue No. 3

112. The Impact of Anti-Monopoly Law on the BHP-Rio Tinto Merger, China Weekly (中国周刊) 15 July 2009

113. Reflections on the Problem of Administrative Monopoly, Journal of Graduate School of Chinese Academy of Social Sciences (中国社会科学院 研究生院学报) 2009, Issue No. 4

114. Defining the Relevant Market in Anti-Monopoly Law, International Business Daily (国际商报) 1 September 2009

115. Anti-Monopoly Law should be a Powerful Tool to Protect Competition, Study Times (学习时报) 25 January 2010

116. Competition Policy Cooperation in Free Trade Zones, Intertrade (国际贸 易) 2011, Issue No. 10

117. Huawei Should Have Won, Science and Technology Daily (科技日报) 2 March 2011

118. Technical Standards, Intellectual Property Rights, and Anti-Monopoly Law, Electronics Intellectual Property (电子知识产权) April 2011

119. The Main Legal Issues in the Broadband Access Competition Case, Price: Theory \& Practice (价格理论与实践) 2011, Issue No. 12 
120. The Enforcement of China's AML for Three Years and the Rule of Law, in 2012 East Asian Conference on Philosophy of Law: East Asian Legal Cultures in the Age of Post-Reception, Angle Publishing Co. (台湾元照出 版社) 2013

121. Reflections on the Anti-Monopoly Case Against China Telecom and China Unicom, SJTU Law Review (交大法学) 2013, Issue No. 2

122. The Theory and Practice of the Extraterritorial Application of China's Anti-Monopoly Law, Price: Theory \& Practice (价格理论与实践) 2014, Issue No. 2

\section{ENGLISH-LANGUAGE PAPERS}

1. Necessity of and Conditions for an Anti-Monopoly Law in China, Working Paper on European Studies, 8 July 2001, Vol. 3

2. The Prospect of Antimonopoly Legislation in China, Washington University Global Studies Law Review, 2002, Vol. 1, Issue No. 1 and 2

3. Issues Surrounding the Drafting of China's Anti-Monopoly Law, Washington University Global Studies Law Review, 2004, Vol. 3, Issue No. 1

4. WTO Competition Policy and its Influence on China, Social Sciences China, Spring 2004

5. Anti-Monopoly Law Vital, China Daily, 22 August 2004

6. The Impacts of the WTO Competition Policy Negotiation in China, ZWeR, 2004, Issue No. 3

7. China Report on Competition Policy, Kobe Law Journal, June 2005, Vol. LV, Issue No. 1

8. Unfair Competition and Anti-Competition, in Masao Ogawa and Iwakazu Takahashi (eds.), Competition Law and Policy in Asia, Kyoto Gakuen University, 2005

9. Topical Issues in China's Antimonopoly Legislation, China Law, 2007, Issue No. 4

10. Anti-Monopoly Law: A Tough Start, Caijing Annual Edition 2008: Forecasts and Strategies, 2008

11. China's New Antimonopoly Law: From Critical Perspective, Italian Intellectual Property Yearbook 2007, 2007

12. Highlights of China's New Antimonopoly Law, Antitrust Law Journal, 2008, Vol. 75, Issue No. 1

13. Anti-Monopoly Law in the Compulsory Licensing of Intellectual Property, Social Sciences in China, February 2008, Vol. 24, Issue No. 1

14. Analysis and Comment on the Anti-Monopoly Law of the People's Republic of China, Frontiers of Law in China, 2009, Vol. 4, Issue No. 3 
15. China's Anti-Monopoly Law: Agent of Competition Enhancement or Engine of Industrial Policy?, Co-authored with Jessica Su in The Goals of Competition Law, Daniel Zimmer (ed.), Edward Elgar, 2012

16. China's Anti-Monopoly Law and the Reform of the Economic System, in Competition Law in the BRICS Countries, A. Emch, J. Regazzini and V. Rudomino (eds.), Kluwer Law International, 2012

17. China's Competition Law in the Global Competition, Concurrences 1-2013 - Conference on Global Competition - Chicago-Kent College of Law, available at http://www.concurrences.com/IMG/pdf/ concurrences_1-2013_conference_global_competition_chicago.pdf

18. Reflections on the Antitrust Case against China Telecom and China Unicom, in The Chinese Anti-Monopoly Law: The First Five Years, A. Emch and D. Stallibrass (eds.), Kluwer Law International, 2013

19. Enforcement under China's Anti-Monopoly Law: So Far, So Good? Coauthored with Adrian Emch, in William E. Kovacic, An Antitrust Tribute, Liber Amicorum Vol. I, N. Charbit, E. Ramundo, A. Chehtova, and A. Slater (eds.) Concurrences 2-2013, www.concurrences.com

20. China: The Competition Law System and the Country's Norm, Coauthored with Jessica Su, in The Design of Competition Law Institutions, E. Fox and M. Trebilcock (eds.), Oxford University Press, 2013

21. Five Years of Implement of China's Antimonopoly Law- Achivements and Challenges, Co-authored with Adrian Emch, Journal of Antitrust Enforcement, Vol.1, No.2, 2013

\section{GERMAN-LANGUAGE PAPERS}

1. Competition and Restrictions on Competition in the Chinese Economy, GRUR International, 1992, Issue No. 7

2. EC Anti-Dumping Law and Chinese Exports to the European Community, Rabels Zeitschrift, 1993, Issue No. 4

3. The Chinese Price System in Economic Reform, Asien, October 1993

4. Theory of Competition and Competitive Market Structure-A Study on the Need for Anti-Monopoly Law in China, in Vergleichendes Kartellrecht, F. Muenzel (eds.), Hamburg 1994

5. Competition Law and China's Socialist Market Economy, in Sozialistische Marktwirtschaft, Soziale Marktwirtschaft, Peter Koslowski and Yunquan Chen (eds.), Physica-Verlag Heidelberg 1996

6. Social Security Law in China's Transition, in Zeitschrift für ausländisches und internationales Arbeits-und Sozialrecht (ZIAS), 3/1996

7. Social Health Insurance in China's Transition, in Zeitschrift für ausländisches und internationales Arbeits-und Sozialrecht (ZIAS), 4/2000 
8. Reform of China's Social Health System, in Sozialrecht und SozialpolitikDeutschland und Europa, Festschrift für Bernd Baron von Maydell, Böcken/Ruland/Steinmeyer (eds.), Luchterhand 2002

9. The Formulation of China's Anti-Monopoly Law, Zeitschrift für Chinesischen Recht, 2/2004

10. The Latest Draft of China's Anti-Monopoly Law, Zeitschrift für Chinesischen Recht, 2/2007

11. The Adoption and Implementation of China's Antitrust Law, Co-authored with Frank Münzel, Recht der Internationalen Wirtschaft (RIW), 7/2008 